\title{
Analisis Kandungan Gizi dan Uji Organoleptik Berbagai Jenis Enbal (Oleh-Oleh Khas Kota Tual) di Kabupaten Maluku Tenggara
}

\author{
Nutrient Content Analysis and Organoleptic Tests of Various Types Enbal (Souvenirs Typical of the \\ City Tual) in Southeast Maluku District
}

\author{
Gelora Helena Augustyn*, Erynola Moniharapon, Arnold Ohoirat \\ Jurusan Teknologi Hasil Pertanian, Fakultas Pertanian, Universitas Pattimura \\ Jl. Ir. M. Putuhena, Kampus Poka, Ambon 97233 \\ *Penulis Korespondensi: E-mail: hgelora@yahoo.com
}

\begin{abstract}
The purpose of this study to determine how much the nutrients contained in each type of enbal and organoleptic tests to determine how much consumen acceptance. This research uses descriptive test with five variables observation with two replications namely: enbal usual, enbal nuts, enbal chocolate and enbal cheese. The results of research to produce the nutrients in enbal cheese ypes are: water content of 7,78\%, ash content of $1,22 \%, 1,39 \%$ protein content, fat content $24,29 \%$ and $65,32 \%$ carbohydrate content. Organoleptic test result with the higest level of preference panel is on enbal cheese with value of 3,56.
\end{abstract}

Keywords: consumer acceptance, enbal, organoleptic tests

\begin{abstract}
ABSTRAK
Tujuan penelitian ini untuk mengetahui berapa besar kandungan gizi yang terdapat dalam setiap jenis enbal dan uji organoleptik untuk mengetahui seberapa besar daya terima konsumen. Penelitian ini menggunakan pengujian deskriptif dengan lima variabel pengamatan dengan dua kali ulangan yaitu: enbal biasa, enbal kacang, enbal coklat, dan enbal keju. Hasil penelitian menunjukkan bahwa kandungan gizi pada jenis enbal keju yaitu kadar air 7,78\%, kadar abu 1,22\%, kadar protein 1,39\%, kadar lemak 4,29\% dan kadar karbohidrat $65,32 \%$. Hasil uji organoleptik dengan tingkat kesukaan panelis tertinggi terhadap rasa yaitu pada jenis enbal keju, dengan nilai 3,46, kesukaan panelis tertinggi terhadap tekstur yaitu pada jenis enbal kacang dengan nilai 2,73 . Kesukaan panlies secara menyeluruh atau overall yang tertinggi terdapat pada jenis enbal keju dengan nilai 3,56.
\end{abstract}

Kata kunci: daya terima konsumen, enbal, uji organoleptik

\section{PENDAHULUAN}

Pangan merupakan komoditas penting dan strategis karena pangan menjadi kebutuhan pokok manusia yang harus dipenuhi oleh setiap rakyat Indonesia (Suismono dan Hidayah, 2011). Diversifikasi pangan merupakan suatu proses pemilihan yang tidak hanya tergantung pada satu jenis pangan, akan tetapi memiliki beragam pilihan atau alternatif terhadap berbagai bahan pangan, pertimbangan rumah tangga untuk memilih bahan makanan pokok keluarga didasarkan pada aspek produksi dan aspek konsumsi pangan. Penganeka- ragaman pangan ditujukan tidak hanya untuk mengurangi ketergantungan akan jenis pangan tertentu, akan tetapi dimaksudkan pula untuk mencapai keberagaman komposisi gizi sehingga mampu menjamin peningkatan kualitas gizi masyarakat (Riyadi, 2003).

Ubi kayu (Manihot esculenta, Crantz) merupakan komoditas tanaman pangan yang mempunyai potensi untuk diolah langsung dari bentuk segarnya maupun diproses terlebih dahulu menjadi berbagai produk setengah jadi seperti tepung (Haloho, 2014). Menurut Suharno (1990), tepung ubi kayu mengandung pati $83,8 \%$, lemak 
$0,9 \%$, protein $1 \%$, serat $2,1 \%$, dan abu $0,7 \%$. Kekurangan ubi kayu adalah rendahnya kandungan protein, sehingga untuk meningkatkan kandungan protein produk olahan yang dihasilkan dari tepung ubi kayu perlu adanya penambahan protein misalnya protein dari kacang-kacangan. Berdasarkan kandungan asam sianidanya $(\mathrm{HCN})$, ubi kayu digolongkan menjadi empat yaitu golongan yang tidak beracun, beracun sedikit, beracun, dan sangat beracun (Muchtadi et al., 2010).

Ubi kayu beracun dikenal di Maluku terlebih khusus Kabupaten Maluku Tenggara sejak berabad-abad lalu. Masyarakat disana biasanya menyebut dengan bahasa lokal yaitu enbal. Enbal merupakan salah satu jenis makanan tradisional masyarakat Kabupaten Maluku Tenggara yang terbuat dari ubi kayu beracun dan rasanya pahit yang disebabkan oleh kandungan $\mathrm{HCN}$, sehingga harus diolah untuk menghilangkan racun tersebut. Kadar HCN yang terdapat dalam ubi kayu dapat dikeluarkan sebagian besar dengan proses penindisan (gepe). Hasil akhir dari proses ini yang biasanya disebut dengan enbal lulun atau tepung enbal yang masih dalam keadaan kasar dan sedikit basah, yang dibaluti dengan karung sebagai media penyaringan. Pada tahap ini akan terjadi pemisahan antara pati dan tepung enbal ketika terjadi penekanan yang berlangsung selama satu hari (24 jam). Kandungan $\mathrm{HCN}$ akan keluar selama proses penindisan berlangsung dan kandungan sianida akan keluar bersamaan dengan proses keluarnya pati enbal tersebut. Enbal pada awalnya diproduksi di Kabupaten Maluku Tenggara hanya dijadikan makanan sewaktu paceklik, namun saat ini permintaan pasar terhadap enbal dan produk olahannya cukup tinggi bahakan berkembang menjadi enbal dengan beranekaragam rasa yaitu coklat, keju dan kacang serta produk buah tangan lainnya. Favorit bagi tamu luar daerah maupun masyarakat lokal yang hendak bepergian keluar daerah (Tapotubun, 2012).

Enbal merupakan salah satu bahan pangan sumber energi karena mengandung karbohidrat tinggi, namun nilai gizi lainnya sangat rendah sehingga diperlukan upaya untuk meningkatkan kandungan gizi enbal. Upaya peningkatan nilai gizi enbal dapat dilakukan dengan cara menambahkan sumber-sumber zat gizi lainnya yaitu pangan protein, lemak, dan vitamin dalam proses pengolahannya misalnya mentega, telur susu, gula, kacang, keju dan lain-lain untuk meningkatkan kualitas dan memberikan nilai tambah bagi produk enbal (Tapotubun, 2012).
Berdasarkan survey, harga enbal yang diproduksi dari Desa Ngilngof kepada pedagang di pasar dan di pertokoan, sebesar Rp. 6.000/bungkus. Setelah itu enbal biasa akan diberikan rasa seperti rasa coklat, rasa keju, dan rasa kacang. Pedagang menjualnya sebungkus dengan harga 25.000 untuk jenis enbal yang dilakukan penambahan kandungan gizi, sdangkan untuk enbal biasa harga penjualan sebungkus sebesar Rp. 10.000. dalam sebulan terjadi empat kali produksi enbal dengan jumlah delapan puluh bungkus/minggu dan semuanya terjual habis, maka dalam sebulan produksi enbal dari Desa Ngilngof sebanyak 240 bungkus/bulan.

Sejalan dengan perkembangan ilmu pengetahun dan teknologi kini telah dilakukan beberapa penelitian dan pengembangan produk olahan enbal baik bentuk, rasa, dan penambahan gizi yang terkandung $\mathrm{d}$ masing-masing produk. penambahan berbagai jenis sumber gizi yang kini terdapat di dalam produk olahan enbal merupakan hal yang harus tetap dikembangkan agar enbal dapat diproduksi dengan berbagai keunikan dan daya tarik, serta daya dorong bagi para pembeli atau konsumen.

\section{METODE PENELITIAN}

\section{Bahan Penelitian}

Bahan yang digunakan dalam penelitian ini adalah enbal coklat, enbal keju, enbal kacang, enbal biasa yang diperoleh dari pasar lokal di Kota Tual. Bahan kimia yang digunakan untuk analisis adalah $\mathrm{NaHPO}_{3}, \mathrm{~Pb}, \mathrm{H}_{2} \mathrm{SO}_{4}$, Na-tiosulfat, larutan sukrosa, karbon aktif, $\mathrm{HgO}, \mathrm{K}_{2} \mathrm{SO}_{4}, \mathrm{H}_{3} \mathrm{BO}_{3}$, dan $\mathrm{HCl}$. Semua bahan kimia yang digunakan adalah pure analysis.

\section{Pelaksanaan Penelitian}

Penelitian ini meliputi dua tahap kegiatan yaitu pengambilan sampel di tempat produksi dan analisis kandungan gizi serta uji organoleptik.

\section{Uji Kimia}

Parameter uji kimia terhadap empat jenis enbal meliputi kadar air metode oven drying (AOAC, 2000), kadar abu dry ashing (AOAC. 2000), kadar protein metode Kjeldahl (AOAC, 2000), kadar lemak metode Soxhlet (AOAC, 2000) dan kadar karbohidrat by difference. 


\section{Uji Organoleptik}

Uji organoleptik dilakukan dengan menggunakan test hedonik pada produk enbal yang meliputi rasa, tekstur dan tingkat kesukaan.

\section{Analisa Data}

Analisa pada penelitian ini adalah data kimia dan organoleptik atau data deskriptif.

\section{HASIL DAN PEMBAHASAN}

\section{Proses Pembuatan Produk Enbal (Oleh-oleh khas Kota Tual)}

Proses pembuatan enbal bunga (biasa) yaitu enbal gepe (lulun) ditumbuk sampai halus. Diayak dengan ayakan halus dan dimasukkan kedalam cetakan (porna) biasanya berbentuk roda buah hati atau bunga, kemudian dipanaskan menggunakan kompor atau api tungku dan hasil akhir yaitu enbal bunga (Tapotubun, 2012).

Berdasarkan hasil wawancara proses pembuatan enbal keju yaitu: enbal gepe ditumbuk sampai halus, diayak dengan ayakan halus dan dimasukkan kedalam cetakan, dipanaskan dengan menggunakan oven atau dikeringkan dengan menggunakan sinar matahari, setelah itu margarin dan gula dikocok bersamaan sampai cair merata dan berwarna putih kemudian pencampuran adonan dengan keju yang telah diparut dan ditaburkan adoanan secara merata diatas enbal yang telah dikeringkan, dijeakan kembali dan dimasukkan ke dalam oven untuk proses pemanasan dan hasil akhir yaitu gurih/ garing dan berwarna kuning.

Proses pembuatan enbal coklat yaitu enbal gepe ditumbuk sampai halus, diayak dengan ayakan halus dan dimasukkan kedalam cetakan. Kemudian dipanaskan dengan menggunakan oven atau dikeringkan dengan menggunakan sinar matahari. Setelah itu margarin dan gula dicampur hingga mengembang dan dan berwarna putih kemudian pencampuran adonan margarin dan gula dicampur dengan coklat dan dioleskan pada enbal yang telah dikeringkan, prose akhir dimasukkan ke dalam oven untuk proses pemanasan sampai mengering dan hasilnya enbal coklat dengan rasa gurih.

Proses pembuatan enbal kacang yaitu enbal ditumbuk sampai halus diayak dengan ayakan halus dan dilakukan pencampuran kacang yang telah disangrai dan telah digiling dengan botol sampai halus dengan tepung enbal yang telah diayak tadi kemudian dicampur dengan gula halus agar terasa manis, dimasukan kedalam cetakan dan dipanaskan dengan menggunakan oven setelah itu dikeringkan kembali dengan menggunakan sinar matahari dan hasil akhir yaitu enbal kacang yang gurih dan siap dikemas.

\section{Analisis Kimia}

Hasil analisis kimia meliputi kadar air, kadar abu, kadar protein, kadar lemak dan kadar karbohidrat pada enbal biasa, enbal kacang, enbal coklat dan enbal keju dapat dilihat pada Tabel 2.

\section{Kadar Air}

Kadar air produk berhubungan erat dengan daya simpannya. Semakin rendah kadar air suatu produk maka daya simpannya diperkirakan akan lebih lama (Yustiani dan Setiawan, 2013). Penentuan kadar air diperlukan sebab berpengaruh terhadap daya simpan enbal. Hasil analisis menunjukkan bahwa kadar air yang tertinggi terdapat pada enbal biasa yaitu sebesar $13,17 \%$ dan diikuti enbal kacang sebesar 9,82\%, enbal coklat sebesar 7,96\% dan enbal keju sebesar 7,78\%. Perbedaan kadar air antara keempat jenis enbal terletak pada proses pengeringan. Berdasarkan hasil wawancara, jenis enbal kacang, enbal coklat dan enbal keju telah melalui dua kali proses pengeringan sehingga pada pengujian kadar air nilainya lebih rendah dibandingkan dengan jenis enbal biasa.

\section{Kadar Abu}

Pengujian kadar abu bertujuan untuk mengetahui besarnya kandungan mineral yang terdapat dala msuatu bahan (Sudarmadji et al., 2010). Hasil analisis menunjukkan bahwa kadar abu yang tertinggi terdapat pada enbal keju sebesar 1,22\%, dan diikuti enbal kacang 0,98\%, enbal coklat sebesar $0,80 \%$ dan enbal biasa $0,50 \%$ (Tabel 1 ). Rendahnya kadar abu pada enbal biasa dikarenakan jenis enbal biasa merupakan produk yang tidak terjadi penambahan kandungan gizi jika dibandingkan dengan jenis produk enbal lainnya. Sedangkan pada jenis enbal keju, kadar abunya cukup tinggi jika dibandingkan dengan dengan jenis enbal kacang, enbal coklat dan enbal biasa dikarenakan didalam keju terdapat susu yang 
memiliki zat-zat penyusunnya seperti kalsium, fosfor dan kalium sehingga mempengaruhi besarnya kandungan mineral pada enbal keju. Menurut Soeparno (2005) keju mengandung mineral yang cukup yaitu $0,87 \mathrm{~g}$ kalsium dan 0,61 $\mathrm{g}$ fosfor.

\section{Kadar Protein}

Protein merupakan zat makanan yang penting bagi tubuh karena selain berfungsi sebagai bahan bakar dalam tubuh juga berfungsi sebagai zat pembangun dan pengatur (Winarno, 2007). Hasil analisis menunjukan bahwa kadar protein tertinggi terdapat pada enbal keju sebesar 1,39\%, diikuti oleh enbal coklat sebesar $1,33 \%$, enbal kacang sebesar 0,90\% dan enbal biasa sebesar $0,62 \%$ (Tabel 1). Rendahnya kadar protein pada enbal biasa dikarenakan jenis enbal biasa merupakan produk yang tanpa dilakukan penambahan zat gizi lain sehingga kadar proteinnya rendah. Sedangkan pada jenis enbal keju dan enbal coklat memiliki kadar protein yang tinggi, hal ini disebabkan oleh adanya penambahan keju dan coklat pada pembuatan enbal sehingga mempengaruhi besarnya kadar protein pada enbal keju maupun enbal coklat. Berdasarkan hasil penelitian Soeparno (2005), kandungan protein pada keju sebesar 23,7 g, sedangkan kandungan protein pada bubuk kakao sebesar $19,59 \mathrm{~g}$ (Hardhani, 2016).

\section{Kadar Lemak}

Lemak merupakan zat makanan yang penting untuk menjaga kesehatan tubuh manusia, selain itu lemak berfungsi sebagai sumber energi yang lebih efektif dibandingkan karbohidrat dan protein (Winarno, 2007). Hasil analisis menunjukkan bahwa kadar lemak tertinggi terdapat pada enbal keju sebesar $24,29 \%$, diikuti oleh enbal 1111

Tabel 2. Hasil analisis kimia beberapa jenis enbal coklat sebesar $20,89 \%$, enbal kacang sebesar $2,81 \%$ dan enbal biasa $0,18 \%$ (Tabel 1). Rendahnya kadar lemak pada enbal biasa dikarenakan jenis enbal biasa merupakan produk asli tepung enbal tanpa pencampuran atau penambahan kandungan gizi atau tidak difortifikasi, sedangkan pada jenis enbal keju, kadar lemaknya cukup tinggi jika dibandingkan dengan jenis enbal kacang dan enbal coklat. Kadar lemak pada kacang yang cukup tinggi mengalami penurunan disebabkan karena proses pemanasan yang berulang-ulang, sedangkan nilai kandungan lemak pada enbal coklat tidak berbeda jauh dengan kandungan lemak pada enbal keju. Menurut Hardhani (2016) kandungan lemak pada bubuk kakao sebesar 13,5\%, sedangkan menurut Soeparno (2005) kandungan lemak keju berkisar antara $20,4-33,53 \%$.

\section{Kadar Karbohidrat}

Karbohidrat merupakan komponen bahan pangan yang berperan sebagai sumber energi (Winarno, 2007). Hasil analisis menunjukkan bahwa kadar karbohidrat tertinggi terdapat pada enbal kacang sebesar $85,49 \%$, dan diikuti berturut-turut oleh enbal biasa sebesar $85 \%$, enbal coklat sebesar $69,02 \%$ dan enbal keju sebesar 65,32\%. Tinggi kadar karbohidrat pada enbal kacang dan enbal biasa disebabkan oleh rendahnya komponen gizi seperti protein, lemak, air dan abu yang terdapat pada kedua enbal tersebut. Menurut Sugito dan Hayati (2006), kadar kabohidrat yang dihitung secara by difference dipengaruhi oleh kandungan nutrisi lain, semakin rendah nutrisi lain maka kadar karbohidrat akan semakin tinggi juga, sebaliknya semakin tinggi komponen nutrisi lain maka kadar karbohidrat akan semakin rendah. Komponen nutrisi yang mempengaruhi besarnya kandungan karbohidrat adalah kandungan protein, lemak, air, dan abu. 11]

\begin{tabular}{lcccc}
\hline \multirow{2}{*}{ Kandungan gizi (\%) } & \multicolumn{4}{c}{ Jenis enbal } \\
\cline { 2 - 5 } & Enbal biasa & Enbal kacang & Enbal coklat & Enbal keju \\
\hline Kadar air & 13,7 & 9,82 & 7,96 & 7,78 \\
Kadar abu & 0,5 & 0,98 & 0,8 & 1,22 \\
Kadar protein & 0,62 & 0,9 & 1,33 & 1,39 \\
Kadar lemak & 0,18 & 2,81 & 20,89 & 24,29 \\
Kadar karbohidrat & 85 & 85,49 & 69,02 & 65,32 \\
(by difference) & & & & \\
\hline
\end{tabular}




\section{Pengujian Organoleptik}

Hasil uji organoleptik terhadap enbal biasa, enbal kacang, dan enbal coklat, dan enbal keju dapat dilihat pda Tabel 2.

Tabel 2. Uji Organoleptik Beberapa Jenis Enbal

\begin{tabular}{lcccc}
\hline \multirow{2}{*}{$\begin{array}{c}\text { Skala } \\
\text { hedonik }\end{array}$} & \multicolumn{4}{c}{ Jenis enbal } \\
\cline { 2 - 5 } & $\begin{array}{c}\text { Enbal } \\
\text { biasa }\end{array}$ & $\begin{array}{c}\text { Enbal } \\
\text { kacang }\end{array}$ & $\begin{array}{c}\text { Enbal } \\
\text { coklat }\end{array}$ & $\begin{array}{c}\text { Enbal } \\
\text { keju }\end{array}$ \\
\hline Rasa & 3,43 & 3,23 & 3,26 & 3,46 \\
$\begin{array}{l}\text { Tekstur } \\
\text { Tingkat }\end{array}$ & 2,33 & 2,73 & 2,6 & 2,56 \\
$\begin{array}{l}\text { kesukaan } \\
\text { (overall) }\end{array}$ & 2,53 & 3,3 & 2,6 & 3,56 \\
\hline
\end{tabular}

\section{Rasa}

Winarno (2007), mengemukakan bahwa rasa lebih banyak melibatkan panca indera lidah. Penginderaan pengecapan dapat dibagi menjadi empat pengecapan utama yaitu asin, asam, manis dan pahit. Rasa makanan dapat dikenali dan dibedakan oleh kuncup pengecapan yang terletak pada papilla (noda merah jingga pada lidah). Agar suatu senyawa dapat dikenali rasanya maka harus larut dalam air liur sehingga dapat mengadakan hubungan mikrofilus dan impulls terbentuk dikirim melalui syaraf kepusat susunan saraf. Hasil penilaian kesukaan panelis terhadap rasa enbal berkisar antara 3,23-3,46 yang secara deskriptif menunjukkan rasa suka. Rata-rata penilaian terhadap rasa tertinggi terdapat pada enbal keju 3,46 , diikuti berturut-turut oleh enbal biasa 3,43, enbal coklat 3,26, dan enbal kacang 3,23. Tingginya penilaian panelis terhadap rasa enbal keju disebabkan oleh adanya rasa khas keju dan rasa manis sumbangan penambahan gula yang terdapat didalam keju, sehingga mempengaruhi penilaian panelis terhadap rasa dari enbal keju dibandingkan dengan rasa dari ketiga jenis enbal lainnya.

\section{Tekstur}

Tekstur yang dimaksud dalam analisis sensoris ini adalah tekstur yang dirasakan oleh panelis pada saat jenis-jenis enbal digigit dan dikunyah. Hasil penilaian panelis terhadap tekstur enbal berkisar antara 2,33-2,73 yang secara deskriptif menunjukkan tekstur agak halus hingga mendekati halus. Rata-rata penilaian panelis terhadap tekstur tertinggi terdapat pada enbal kacang yaitu sebesar 2,73 diikuti berturut-turut oleh enbal coklat 2,6, enbal keju 2,56, dan enbal biasa 2,33 . Tingginya penilaian panelis terhadap tekstur enbal kacang disebabkan oleh adanya penambahan kacang membuat tekstur enbal lebih renyah pada saat digigit dan lembut pada saat dikunyah, sehingga mempengaruhi penilaian panelis terhadap tekstur dari enbal kacang dibandingkan ketiga jenis enbal lainnya.

\section{Tingkat Kesukaan (overall)}

Pengujian secara keseluruhan (overall) merupakan penilaian terhadap semua faktor mutu yang meliputi rasa dan tektur yang dimaksudkan untuk mengetahui tingkat penerimaan panelis terhadap jenis-jenis enbal baik yang biasa maupun yang telah difortifikasi, bagaimana daya tarik panelis dalam melakukan pengujian secara keseluruhan. Pengujian oleh panelis terhadap tingkat kesukaan (overall) yang tertinggi yaitu pada jenis enbal keju dengan nilai 3,56 (mendekati sangat suka) dan penilaian untuk tingkat kesukaan (overall) yang terendah yaitu pada jenis enbal biasa yaitu 2,53 (mendekati suka).

Hasil pengujian terhadap tingkat kesukaan panelis secara menyeluruh terhadap jenis enbal keju dikarenakan panelis lebih menyukai kenampakkan meliputi warna, bentuk, ukuran, kemasan dan rasa sehingga panelis lebih cenderung untuk memilih jenis enbal keju dibandingkan ketiga jenis enbal lainnya.

\section{KESIMPULAN}

Berdasarkan hasil penelitian dan pembahasan maka dapat disimpulkan bahwa enbal keju memiliki nilai kadar air 7,78\%, kadar abu $1,22 \%$, kadar protein 1,39\%, kadar lemak 24,29\%, dan kadar karbohidrat 65,32\%, serta uji organoleptik meliputi rasa 3,46 (suka), tekstur 2,56 (mendekati halus), dan secara overall 3,56 (mendekati sangat suka).

\section{DAFTAR PUSTAKA}

AOAC. 2000. Official Methods of Analysis Association of Official Analytical Chemist. Inc. Arlington Virginia.

Haloho, J.D. 2014. Pengolahan ubi kayu dalam upaya percepatan diversifikasi pangan di Kalimantan Barat. Prosiding Seminar Hasil 
Penelitian Tanaman Aneka Kacang dan Umbi. Balai Tanaman Aneka Kacang dan Umbi. Bogor. Hal 775-786.

Hardhani, M.S.P. 2016. Pengaruh Konsentrasi

Penambahan Bubuk Cokelat Terhadap Aroma dan Rasa dalam Pembuatan Yoghurt Berbahan Dasar Susu Kambing Etawa. [Skripsi] Program Studi Pendidikan Biologi Jurusan Pendidikan Matematika dan Ilmi Pengetahuan Alam Fakultas Keguruan dan Ilmu Pendidikan Universitas Sanata Dharma. Yogyakarta.

Muchtadi, T.R., Sugiyono, dan F. Ayustaningwarno. 2010. Ilmu Pengetahuan Bahan. Alfabeta. Bandung.

Riyadi. 2003. Diversifikasi Pangan. Badan Penelitian dan Pengembangan Pertanian. Jakarta.

Soeparno. 2005. Ilmu dan Teknologi Daging. Cetakan III. Gadjah Mada University Press. Yogyakarta.

Sudarmadji, S., B. Haryono, dan Suhardi. 2010. Analisa Bahan Makanan dan Pertanian. Liberty. Yogyakarta.
Sugito, dan A. Hayati. 2006. Penambahan daging ikan gabus (Ophicepallus strianus) dan aplikasi pembekuan pada pembuatan pempek gluten. Jurnal Ilmu-Ilmu Pertanian Indonesia 8: 147-151.

Suharno. 1990. Rancang bangun dan introduksi model alat penepung ketela pohon. Laporan Pengabdian pada Masyarakat. Fakultas Teknologi Pertanian. Universitas gadjah Mada.Yogyakarta.

Suismono, dan N. Hidayah. 2011. Pengembangan diversifikasi pangan pokok lokal. Pangan 20: 295-313.

Topatubun, E.J. 2012. Kandungan Gizi dan Masa Simpan Makana Tradisional Enbal Asal Kepulauan Kei Dengan Penambahan Tepung ikan Layang. [Tesis] Sekolah Pasca Sarjana, Institut Pertanian Bogor. Bogor.

Winarno, F.G. 2007. Kimia Pangan dan Gizi. Gramedia Pustaka Utama. Jakarta.

Yustiani, dan B. Setiawan. 2013. Formulasi bubur instan menggunakan komposit tepung kacang merah dan pati ganyong sebagai makanan sapihan. Jurnal Gizi dan Pangan 8: 95-102. 